Boston University School of Law

Scholarly Commons at Boston University School of Law

Faculty Scholarship

$10-2013$

\title{
Injunctive and Reverse Settlements in Competition-Blocking Litigation
}

Keith N. Hylton

Boston University School of Law

Sungjoon Cho

Chicago-Kent College of Law

Follow this and additional works at: https://scholarship.law.bu.edu/faculty_scholarship

Part of the Antitrust and Trade Regulation Commons, Law and Economics Commons, and the Litigation Commons

\section{Recommended Citation}

Keith N. Hylton \& Sungjoon Cho, Injunctive and Reverse Settlements in Competition-Blocking Litigation, in 36 European Journal of Law and Economics 243 (2013).

Available at: https://scholarship.law.bu.edu/faculty_scholarship/378

This Article is brought to you for free and open access by Scholarly Commons at Boston University School of Law. It has been accepted for inclusion in Faculty Scholarship by an authorized administrator of Scholarly Commons at Boston University School of Law. For more information, please contact lawlessa@bu.edu.

BOSTON UNIVERSITY 


\section{HEINONLINE}

DATE DOWNLOADED: Wed Sep 21 22:09:58 2022

SOURCE: Content Downloaded from HeinOnline

Citations:

Bluebook 21st ed.

Keith N. Hylton \& Sungjoon Cho, Injunctive and reverse settlements in competition-blocking litigation, 36 EUR. J.L. \& ECON. 243 (2013).

ALWD 7th ed.

Keith N. Hylton \& Sungjoon Cho, Injunctive and reverse settlements in competition-blocking litigation, 36 Eur. J.L. \& Econ. 243 (2013).

APA 7th ed.

Hylton, K. N., \& Cho, S. (2013). Injunctive and reverse settlements in competition-blocking litigation. European Journal of Law and Economics, 36(2), 243-270.

Chicago 17th ed.

Keith N. Hylton; Sungjoon Cho, "Injunctive and reverse settlements in competition-blocking litigation," European Journal of Law and Economics 36, no. 2 (October 2013): 243-270

McGill Guide 9th ed.

Keith N. Hylton \& Sungjoon Cho, "Injunctive and reverse settlements in competition-blocking litigation" (2013) 36:2 Eur JL \& Econ 243.

AGLC 4th ed.

Keith N. Hylton and Sungjoon Cho, 'Injunctive and reverse settlements in competition-blocking litigation' (2013) 36(2) European Journal of Law and Economics 243

MLA 9th ed.

Hylton, Keith N., and Sungjoon Cho. "Injunctive and reverse settlements in competition-blocking litigation." European Journal of Law and Economics, vol. 36, no. 2, October 2013, pp. 243-270. HeinOnline.

OSCOLA 4th ed.

Keith N. Hylton \& Sungjoon Cho, 'Injunctive and reverse settlements in competition-blocking litigation' (2013) 36 Eur JL \& Econ 243

Provided by:

Fineman \& Pappas Law Libraries

-- Your use of this HeinOnline PDF indicates your acceptance of HeinOnline's Terms and Conditions of the license agreement available at https://heinonline.org/HOL/License

-- The search text of this PDF is generated from uncorrected OCR text.

-- To obtain permission to use this article beyond the scope of your license, please use: Copyright Information 


\title{
Injunctive and reverse settlements in competition-blocking litigation
}

\author{
Keith N. Hylton • Sungjoon Cho
}

Published online: 17 November 2011

(C) Springer Science+Business Media, LLC 2011

\begin{abstract}
We distinguish standard settlements, in which the status quo is preserved, and injunctive settlements, which prohibit the defendant's activity. The reverse (payment) settlement is a special type of injunctive settlement. We examine the divergence between private and social incentives to settle and policies that would minimize socially undesirable injunctive and reverse settlements (e.g., banning reverse settlements). The results are applied to competition-blocking litigation, such as patent infringement and antidumping.
\end{abstract}

Keywords Litigation - Reverse payment settlements - Injunctive settlements · Patent infringement litigation · Waiver agreements · Antidumping

JEL Classification $\mathrm{F} 13 \cdot \mathrm{K} 21 \cdot \mathrm{K} 33 \cdot \mathrm{K} 41 \cdot \mathrm{L} 43 \cdot \mathrm{O} 31$

\section{Introduction}

This paper explores the economics and the competition policy implications of injunctive settlements-settlements that implement the terms of an injunction sought by the plaintiff. The best known examples of such settlements are observed

An earlier version of this material appeared under the title "The Economics of Injunctive and Reverse Settlements". After that earlier working paper grew to roughly 50 pages, we separated the material examining reverse settlements generally (e.g., in the torts setting) from the material examining competition policy implications. This paper focuses on competition policy implications.

K. N. Hylton (凹)

Boston University, Boston, MA, USA

e-mail: knhylton@bu.edu

S. Cho

Chicago-Kent College of Law, Chicago, IL, USA 
in the context of competition-blocking litigation, such as patent infringement and antidumping litigation.

In the patent-antitrust context, a great deal of controversy surrounds "reverse settlements" (more precisely, reverse payment settlements) in patent infringement litigation. The reverse settlement involves a plaintiff in a patent infringement suit (for example, a pharmaceutical company with a patent on a drug) paying the defendant (for example, a manufacturer of a generic drug) to settle the case. The reverse settlement typically includes an agreement that the defendant will restrict sales of the allegedly infringing drug. At present, federal circuit courts are split on the legality, under the antitrust laws, of reverse settlements in patent litigation. ${ }^{1}$

In the antidumping context, a similar type of settlement is observed. These are administrative proceedings in which the plaintiff is technically the United States Department of Commerce. However, the Commerce Department's proceeding is brought on behalf of or at the instigation of domestic firms that claim that a foreign seller has "dumped" goods at unreasonably low prices in their domestic market. Some antidumping disputes are resolved when a complaint is withdrawn and the foreign seller increases its price in the domestic market (Prusa 1992). In other words, the foreign seller opts for some share of the domestic cartel's profits rather than continuing to fight the dumping charge. As we will see below, this type of settlement is indistinguishable in economic terms from the reverse settlement.

This paper draws some practical insights on reverse settlements in competitionblocking litigation. We start with a simple model of injunctive and reverse settlements ${ }^{2}$ and summarize its implications for the economics of settlements. The model identifies general conditions under which injunctive settlements and reverse settlements are likely to be observed, and shows that in the competition-blocking scenario virtually all injunctive settlements will be in the form of reverse (payment) settlements. In general, reverse settlements (in comparison to no settlement) are likely when the stakes associated with the injunction are large relative to damages and litigation costs.

We then turn to normative questions, specifically the conditions under which injunctive and reverse settlements are likely to be harmful to social welfare in the context of competition-blocking litigation. We also examine the divergence between private and social incentives to settle and policies that would minimize socially undesirable injunctive settlements. If reverse settlements were barred, the potential litigants could switch to predispute waivers. We examine the divergence between the private and the social incentives to waive in the competition-blocking context, as well as policies to minimize socially undesirable waivers. One new policy examined is an optimal penalty that would align private and social incentives to settle or to enter into a predispute waiver agreement.

\footnotetext{
1 Favoring legality: In re Tamoxifen Citrate Antitrust Litig., 466 F.3d 187, 190 (2d Cir. 2006) (refusing to impose antitrust liability where generic accepted payment in exchange for agreement to delay entry); Schering-Plough Corp. v. FTC, 402 F.3d 1056, 1076 (11th Cir. 2005) (same); In re Ciprofloxacin Hydrochloride Antitrust Litig., No. 08-1097 (Fed. Cir. Oct. 15, 2008) (same), available at http:/www.cafc.uscourts.gov/opinions/08-1097.pdf. Opposing legality: In re Cardizem CD Antitrust Litig., 332 F.3d 896, 908 (6th Cir. 2003) (finding per se antitrust violation in agreement to delay generic entry); Andrx Pharm., Inc., v. Biovail Corp. Int'l, 256 F.3d 799 (D.C. Cir. 2001) (same).

2 The model of settlement applied here is from Hylton and Cho (2010).
} 
We find that in the antidumping context there is a strong case for banning reverse settlements. In patent-antitrust, the case for holding reverse settlements per se unlawful under the antitrust laws is unpersuasive. ${ }^{3}$ A reverse settlement may signal a weak claim on the part of the plaintiff, but it may also occur because the stakes associated with the injunction are high. The stakes may be high because of the anticompetitive potential of the injunctive settlement, or because the injunction supports market development and innovation incentives. The mere observation of a reverse settlement would not permit an observer to know whether the settlement is socially beneficial or detrimental. The model below details the economic factors that should be considered in a legal analysis (e.g., rule of reason in antitrust) of reverse settlements in patent infringement litigation.

\section{Background}

Injunctive and reverse settlements can be observed in any area of litigation in which plaintiffs seek to enjoin some activity of the defendant. One common example of this type of litigation is in the nuisance setting, where the plaintiff may sue for damages and to enjoin the defendant's nuisance-generating activity. A settlement could involve the defendant agreeing to discontinue his activity.

Competition-blocking litigation provides the most prominent examples today of injunctive and reverse settlements. Competition-blocking litigation typically involves a plaintiff (incumbent firm) with market power against a defendant (entrant) who intends to undercut the plaintiff in its market. The plaintiff's interest is to maintain the profit it earns from its monopoly. The defendant's interest is to maintain the profit it earns from undercutting the price set by the plaintiff.

Let $G_{p}$ represent the gain to the incumbent monopolist from blocking competition and $L_{d}$ represent the loss to the entrant when competition is blocked. The interests at stake in competition-blocking litigation can be described by Fig. 1. The rectangle denoted $G_{p}$ shows the profit earned by the plaintiff (incumbent monopolist) when he charges the monopoly price $p_{m}$ rather than the competitive price (given his cost structure) $p_{c}$. The social cost (or deadweight loss) from monopolization is shown by the triangular area $W$.

The competitive price for the plaintiff $p_{c}$ is equal to its unit cost. The rectangle denoted $L_{d}$ represents the profit earned by the defendant entrant when he undercuts the unit cost of the plaintiff. The minimum price for the defendant is $p_{r}$, which is equal to its unit cost.

\footnotetext{
3 This conclusion is in opposition to that taken by the FTC in federal court litigation and of several commentators, see Crane (2002), Cotter (2004), Hovenkamp et al. (2003), and Hemphill (2006). In addition, the European Commission has issued a report on patent practices, including settlements, that suggests the possibility of legal action against major pharmaceutical companies that have entered into reverse settlement agreements with generic sellers, see http:/europa.eu/rapid/pressReleasesAction.do? reference $=$ MEMO/08/746\& format $=H T M L$ \&aged $=0$ \&language $=E N \&$ guilanguage $=$ en. On February 3d, 2009, US senators Herb Kohl and Chuck Grassley introduced legislation to ban reverse patent settlements in pharmaceutical patent disputes, see http:/kohl.senate.gov/press/09/02/2009203B 19.html.
} 


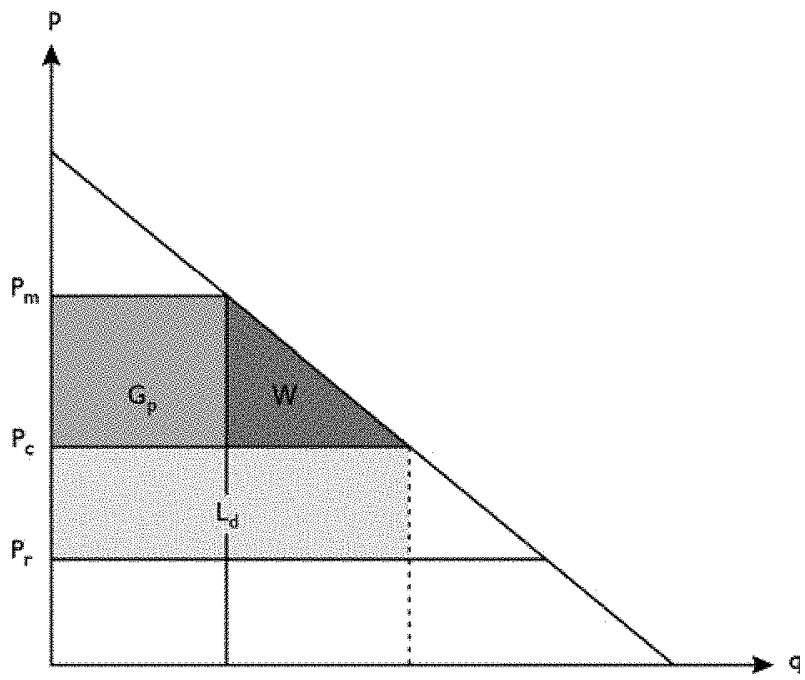

Fig. 1 Diagram of Plaintiff's Gain $\left(G_{p}\right)$, Defendant's Loss $\left(L_{d}\right)$, and Deadweight Loss (W)

In the antidumping context, a domestic cartel earns the profit shown by $G_{p}$ when it excludes foreign competition. If the cartel cannot block foreign competition, the foreign firms will enter and charge a price slightly below $p_{c}$ and take the market to themselves, capturing $L_{d}$. Since $L_{d}$ represents the profit available to the foreign sellers, it also represents the loss imposed on them by a competition-blocking injunction.

In the patent-antitrust context, the drug patent holder charges $p_{m}$ when it blocks competition from the generic entrant. If it cannot block the generic's entry, the patent holder will reduce its price to $p_{c}$. Still, the generic seller may be able to earn a profit of as much as $L_{d}$ by undercutting $p_{c}{ }^{4}$

\section{Model}

\subsection{Economics of litigation with injunctive settlements}

In this part we examine the incentives driving parties to litigate and to settle when the lawsuit seeks both damages and an injunction (injunctive litigation). The standard economic analysis of litigation examines the lawsuit for damages (standard litigation). Since the economic analysis of settlement is familiar, we will focus on the model's application to competition-blocking lawsuits.

The litigation process is one in which the plaintiff files a complaint, which is then either settled or prosecuted to a final judgment. The final judgment enjoins the

\footnotetext{
${ }^{4}$ This is an admittedly simple version of competition between an incumbent and a generic seller. In many instances the generic entrant sells to price-sensitive consumers while the incumbent sells to brandloyal consumers. As a result, the entry of a generic is sometimes followed with a price increase by the incumbent seller, see Blair and Cotter (2002).
} 
defendant's activity. In a competition-blocking lawsuit, the final judgment would require the defendant to increase its price and cede market share, thus losing its gain from low-price entry, and perhaps to transfer money as compensation to the plaintiff.

In the patent infringement setting, the plaintiff prosecutes his own claim against the low-price defendant. That claim can lead to an injunction against the generic seller as well as damages for the losses suffered by the plaintiff from infringement. In the antidumping context, a government agency (the US Department of Commerce) prosecutes the claim. But the plaintiff (the industry whose interests are represented by the Department of Commerce) can lay claim to the antidumping penalty under the "Byrd Amendment" (repealed in 2005). ${ }^{5}$ The final judgment typically requires the defendant to increase its price, thus losing its gain from lowprice entry, and to pay an antidumping penalty.

Let $P_{p}=$ the plaintiff's perception of the probability of winning, $J_{p}=$ the payoff to the plaintiff and $C_{p}=$ the cost to the plaintiff. In the patent infringement setting, the plaintiff's perception of the probability of winning is determined by his prediction that the court will find that infringement occurred, which is a function of the patent's validity and the defendant's conduct. In the antidumping context, the plaintiff's perception of the likelihood of victory is high in comparison to civil litigation because disputes are tried within an agency that is charged with representing plaintiffs' interests (Cho 2009).

Complaints are filed when the net reward, $P_{p} J_{p}-C_{p}$, is positive (Shavell 1982a). Since the plaintiff's judgment consists of $G_{p}=$ the gain the plaintiff gets from the injunction, and $D=$ the damage award, he will file a claim when $P_{p}\left(G_{p}+D\right)-C_{p}>0$.

Let $P_{d}=$ the defendant's prediction of the plaintiff's probability of winning (likelihood of finding a violation), $C_{d}=$ the litigation cost borne by the defendant, and $J_{d}=$ the defendant's assessment of the cost of the judgment. Since the judgment consists of the loss to the defendant from the injunction and the damage award, $J_{d}=L_{d}+D$, the defendant's cost of the lawsuit is $P_{d}\left(L_{d}+D\right)+C_{d}$. In the context of competition-blocking litigation, the cost of the judgment to the defendant consists of the loss that results from being forced to raise price and cede market share plus the amount the defendant will have to pay as compensation to the plaintiff.

If the expected net gain to the plaintiff from the lawsuit is less than the defendant's total cost of litigation, the parties will settle. Settlement therefore occurs when $P_{p} G_{p}-P_{d} L_{d}+\left(P_{p}-P_{d}\right) D<C_{p}+C_{d}$, which is the familiar settlement condition of the Landes-Posner-Gould model. ${ }^{6}$ Since the settlement payment must exceed the expected net reward to the plaintiff from suing and since the expected net reward must be positive for the plaintiff to have a credible claim of suing, the settlement will involve a (positive) payment from the defendant to the plaintiff.

\footnotetext{
5 On the Byrd Amendment, see "Byrd's Bad Idea is Back, Wall Street Journal, Opinion Section, Monday, August 11,2008, at A14. Although repealed in 2005, there have been efforts to reenact the Byrd Amendment".

${ }^{6}$ This follows from $P_{p}\left(G_{p}+D\right)-C_{p}<P_{d}\left(L_{d}+D\right)+C_{d}$. This assumes that the probability of an injunction is the same as the probability of an award of damages. That may not be valid in all cases. To keep the model simple, we will stick with this assumption. The results are easily changed for the case in which the probabilities differ.
} 
However, the economics of settlement in injunctive litigation are not fully described by the Landes-Posner-Gould model, because that model ignores settlements that implement the injunction sought by the plaintiff (Hylton and Cho 2010). For example, in the competition-blocking context, a settlement implementing the terms of the injunction sought by the plaintiff involves the defendant raising its price or exiting the market in order to let the plaintiff firm or cartel sell at the monopoly price.

In the injunctive settlement the defendant accepts the terms of the injunction sought by the plaintiff. Such a settlement is desirable to the defendant if the total cost of the settlement to the defendant is less than the total cost of the lawsuit, or, equivalently, $S+L_{d}<P_{d}\left(L_{d}+D\right)+C_{d}$, where $S$ is the settlement amount. The settlement is desirable to the plaintiff if the sum of the transfer and the gain from the injunction exceed his net payoff from the lawsuit: $S+G_{p}>P_{p}\left(G_{p}+D\right)-C_{p}$. It follows that the injunctive settlement will be observed if $\left(1-P_{d}\right) L_{d}-\left(1-P_{p}\right) G_{p}+\left(P_{p}-P_{d}\right)$ $D<C_{p}+C_{d}$. Unlike the standard settlement, the injunctive settlement may require a payment from plaintiff to defendant, which is the reverse payment settlement.

Since the reverse settlement is controversial, it is worthwhile to examine the conditions under which it will be observed. The foregoing implies that the reverse settlement will be observed when $L_{d}>P_{d}\left(D+L_{d}\right)+C_{d}$ and $G_{p}>P_{p}(D+$ $\left.G_{p}\right)-C_{p}$. Suppose the defendant's loss from an injunction is large relative to the damages and litigation cost. Since an injunctive settlement would require the defendant to bear the loss from the injunction with certainty, while litigation involves only a risk of the loss, the defendant will demand to be paid in order to accept the injunctive settlement. Also, as the defendant becomes more optimistic, he will demand a payment in order to settle. Thus, reverse settlements are more likely when the plaintiff's likelihood of victory is low or when the stakes $\left(L_{d}, G_{p}\right)$ are high.

The case of consistent beliefs $\left(P_{d}=P_{p}=P\right)$ is important because it reflects the circumstances in some competition-blocking proceedings (e.g., antidumping). If transaction costs are low some type of settlement (standard or injunctive) will always occur under consistent beliefs (Hylton and Cho 2010).

\subsection{Competition-blocking litigation}

In this part we establish a general result for settlements in competition-blocking litigation. Recall that the competition-blocking scenario involves a plaintiff/ incumbent and a defendant/entrant. Knowing that the incumbent will file a competition-blocking complaint, the entrant will enter when and only when the gain from entry is greater than the expected cost of litigation $L_{d}>P_{d}\left(D+L_{d}\right)+C_{d}$. However, recall that an injunctive settlement will be desirable to the defendant only when $S+L_{d}<P_{d}\left(L_{d}+D\right)+C_{d}$. It follows that in the competition-blocking scenario:

Proposition 1 All injunctive settlements of competition-blocking litigation will be in the form of reverse payment settlements.

The intuition behind this statement is straightforward. Since entry occurs only when the gain to the entrant exceeds the expected cost of litigation, the entrant will 
demand a payment in order to accept the terms of the injunctive settlement. In the remainder, we will apply this result to specific areas of competition-blocking litigation.

\section{Applications of model to competition-blocking litigation}

The preceding part focused on the incentives for injunctive settlements and contrasted those incentives with the analysis of standard settlements. Allowing for injunctive settlements expands the range of settlement agreements available to the parties, and explains the observation of reverse settlements.

Our focus here is on specific types of competition-blocking litigation, specifically antidumping proceedings and patent infringement litigation. While we have emphasized positive analysis to this point, most of the issues examined below are normative. We will identify the factors that determine the welfare effects of injunctive settlements of competition-blocking litigation.

\subsection{Antidumping}

Before examining the implications of the foregoing for antidumping litigation, we should set out some details on the antidumping process. Antidumping investigations and proceedings are conducted by two federal agencies, the International Trade Administration (part of the United States Department of Commerce) and the International Trade Commission (Cho 2009). An investigation is carried out in response to a complaint filed by a group of domestic firms, ${ }^{7}$ and seeks to determine whether the domestic firms have suffered a material injury (Cho 2009). If the ITC's preliminary injury determination is positive, the ITA issues its own preliminary determination on the existence of dumping, which is defined as a domestic sale at less than fair value. ${ }^{8}$ The two agencies subsequently issue final determinations on dumping and injury, respectively.

Because the investigation and "prosecution" are carried out by government agencies, the litigation costs borne by the domestic complainants are relatively small. Conversely, the litigation costs borne by foreign defendants are relatively large. Defendants are forced to litigate against a government agency that works on behalf of domestic complainants, and under procedural rules that are biased in favor of domestic complainants and burdensome on foreign defendants (Cho 2009). If there is a finding of remediable dumping, the ITA calculates a damage award that is equal to the difference between the agency's estimated "home price" for the imported item (fair value) and the actual price of the item in the import market. This difference is known as the dumping margin.

Although the agency's only remedy is to impose antidumping duties to the extent of the dumping margin, the final judgment often has the effect of requiring the

\footnotetext{
${ }^{7}$ The current antidumping statute permits domestic producers to petition relevant government agencies to investigate alleged dumping practices by foreign producers. 19 U.S.C. $\$ 1673 \mathrm{a}(\mathrm{b})(1)$.

819 U.S.C. $\$ 1673$ b(b).
} 
defendant to increase its price and cede market share, thus losing its gain from lowprice entry. In addition, under the Byrd Amendment (repealed in 2005), the antidumping penalty is transferred to the complainants.

In terms of the model in this paper, antidumping proceedings can be described as a setting in which $C_{p}$ is small, ${ }^{9} C_{d}$ is large, ${ }^{10}$ and $P$ is high. Moreover, $P$ will be the same for both plaintiff and defendant, since both know that the process is biased in favor of plaintiffs. We will treat antidumping proceedings as consistent-belief disputes.

Although the proceeding is undertaken by the government, the plaintiff domestic cartel has the option of withdrawing its complaint against the foreign seller (or threatening to file the complaint and then never filing it). Withdrawing a complaint is equivalent to settling the dispute. ${ }^{11} \mathrm{We}$ will therefore treat the antidumping process as a form of private litigation between the plaintiff domestic cartel and the foreign seller.

Given that the probability of plaintiff victory is high, injunctive settlements are likely in antidumping litigation. In addition, injunctive settlements are likely if the plaintiff cartel's gain is greater than the foreign seller's loss from the injunction ( $L_{d}<G_{p}$ ), a condition that is likely to hold. Finally, in the antidumping context transaction costs will rule out the standard settlement that preserves the status quo. ${ }^{12}$ The plaintiff cartel will be unlikely to accept and unable to enforce an agreement in which they receive a side payment from the foreign entrant in order to relinquish the market to the foreign firm. Given this, we explore only the injunctive settlement here.

In the antidumping context, injunctive settlements are not only likely, but they will virtually always be observed in the form of reverse payment settlements. To see this, consider the following application of the model to the antidumping scenario.

Given the threat of an antidumping prosecution, the foreign entrant will enter the market when $L_{d}-P\left(D+L_{d}\right)-C_{d}>0$, or when $P<P_{e} \equiv\left(L_{d}-C_{d}\right) /\left(L_{d}+D\right)$. The plaintiff (incumbent domestic cartel) will file a claim when $P\left(G_{p}+D\right)-$ $C_{p}>0$, or when $P>P_{f} \equiv C_{p} /\left(G_{p}+D\right) .^{13}$ Thus, entry occurs and an antidumping claim will be filed for $P_{f}<P<P_{e}$. From this it follows that:

Proposition 2 All settlements of antidumping prosecutions will be in the form of reverse payment (injunctive) settlements.

\footnotetext{
${ }^{9}$ Petitioners can expect the government to absorb most of the litigation costs under the statutory proceeding, see Calvani and Tritell (1986).

${ }^{10}$ An antidumping proceeding imposes enormous costs on the defendants, see Music Centers S.N.C. Di Luciano Pisoni \& C. v. Prestini Musical Instruments Corp, 874 F.Supp. 543, 547 (1995). Therefore, an antidumping petition itself can be a very effective method of non-price predation against small yet efficient foreign producers. The existence of such non-price predation tends to facilitate an injunctive settlement between antidumping petitioners and respondents. Cho (2009)

11 Taylor (2001) observes that some antidumping cases withdrawn during the period 1990-1997 revealed the same pattern of changes in price and quantity as observed in collusive agreements.

${ }^{12}$ It might seem at first glance that the standard settlement should be ruled out by the assumption of consistent beliefs $\left(P_{d}=P_{p}=P\right)$. But even in the consistent-beliefs case a standard settlement may occur when $L_{d}>G_{p}$.

13 The entry constraint exploited in this model is emphasized in Higgins (2002).
} 
This proposition follows from two points established already. First, recall that standard settlements will not be observed because of transaction costs. Second, note that since entry occurs only when $P<P_{e}, L_{d}-P\left(D+L_{d}\right)+C_{d}>0$, for all such $P$, and the rest follows from Proposition 1 .

In addition to the finding that the only type of settlement that will be observed is the reverse payment settlement, this model also implies such settlements will be common.

Proposition 3 If the plaintiff/incumbent's gain is greater than the entrant's loss from the injunction $\left(L_{d}<G_{p}\right)$, then all antidumping prosecutions will settle with a reverse payment. If the plaintiff/incumbent's gain is less than the entrant's loss from the injunction $\left(L_{d}>G_{p}\right)$, then settlements will be observed when and only when

$$
P_{e}>P>1-\frac{C_{d}+C_{p}}{L_{d}-G_{p}} .
$$

The proof of this claim follows straightforwardly from the general settlement conditions described in the first part of this paper. First, let $\tilde{S}=-S$, since we are dealing with only reverse payment settlements. A settlement will occur when $(1-P) L_{d}-C_{d}<\tilde{S}<(1-P) G_{p}+C_{p}$. Equivalently, settlement occurs when $(1-P)\left(L_{d}-G_{p}\right)<C_{p}+C_{d}$, from which the result follows. This argument assumes $P_{f}<P<P_{e}$.

Example 1 Consider an example that captures some of the features of antidumping litigation. Suppose the gain to the plaintiff cartel (alternatively, the potential domestic cartel profit) is $\$ 500$ and the loss to the defendant foreign seller is $\$ 200$. The cost of litigation is $\$ 1$ for the plaintiff domestic cartel (because the government, in effect representing the domestic cartel, bears most of the expenses) and $\$ 20$ for the defendant. The probability of plaintiff victory is $90 \%$. The damage award, which is equal to the dumping margin, is $\$ 10$. This is not necessarily a compensatory measure; it may exceed actual losses by the plaintiff. In order to accept an injunctive settlement, the defendant has to consider whether the cost of such a settlement, $S+\$ 200$, is less than the cost of litigation, (.9)(\$10) $+(.9)(\$ 200)+\$ 20$; which is true for any settlement $S<\$ 9$. In order to prefer the injunctive settlement the plaintiff considers whether the settlement payoff $S+\$ 500$ is greater than the litigation payoff $(.9)(\$ 500)-\$ 1+(.9)(\$ 10)$; which is true for $S>-\$ 42$. Given Proposition 2, a reverse payment injunctive settlement will occur with a payment from the plaintiff to the defendant that satisfies $\$ 0<\tilde{S}<\$ 42$.

The reverse payment settlement in this example requires the plaintiff domestic cartel to drop its complaint against the foreign seller and the foreign seller to cede market share to the plaintiff cartel. The settlement might involve the plaintiff domestic cartel either sharing part of its profits or paying a sum, as long as the amount is no greater than $\$ 42$, to the defendant foreign seller. Or the arrangement may be one in which foreign seller both receives a reverse payment and is permitted to continue selling in the domestic market at a higher price. Suppose the reverse payment is $\$ 25$. This is $5 \%$ of the potential cartel profit of $\$ 500$. One way to carry 
out such a settlement would be to assign $5 \%$ of the domestic market to the foreign seller. $^{14}$

\subsection{Antidumping continued: welfare implications}

In antidumping disputes, the gain to the domestic cartel from ousting the foreign seller comes out of the potential consumer surplus available to domestic consumers. The cartel's payoff is not attributable to efficiency gains that result from the exclusion of the foreign seller. The end result of the injunction, or the injunctive settlement, is unambiguously inefficient.

The foregoing analysis shows that reverse injunctive settlements are more likely as the probability of plaintiff victory increases and as the plaintiff's gain from the injunction increases relative to the defendant's loss. When the reverse settlement results primarily because the plaintiff's probability of victory is very high (i.e., close to one, subject to the constraint that entry is profitable) it reflects the parties' desire to avoid litigation costs. Injunctive settlement in this case reflects the outcome likely to result from litigation, and therefore is unlikely to harm social welfare.

When the reverse injunctive settlement occurs primarily because the plaintiff's gain is greater than the defendant's loss $\left(L_{d}<G_{p}\right)$, then there is reason to worry that injunctive settlements are especially harmful to social welfare. The reason is, as Fig. 1 shows, the gain to the plaintiff will be positively correlated with the social welfare loss. Indeed, consider the case of an injunctive settlement where the plaintiff's gain is both substantial and only slightly greater than the defendant's loss. The loss in social welfare is at its greatest, because the injunction excludes from the market a foreign seller with a big cost advantage over the domestic firms. ${ }^{15}$

We have confined ourselves to antidumping cases as a special type of competition-blocking litigation, where the injunction has an inefficient result. The question we have considered so far is if the injunctive settlement is a signal, in this set of instances, of particularly worrisome cases. The answer is yes.

Should the injunctive settlement be banned? The injunctive settlement should be banned if

$$
(1-P)\left(W+L_{d}\right)>C_{p}+C_{d} .
$$

If this holds, the payoff to society from cases in which courts deny injunctions (i.e., the social gain from competitive entry) exceeds the costs generated by litigating those cases. Given this, injunctive settlements reduce social welfare. Since all of the injunctive settlements will be reverse payment settlements, we will consider whether reverse injunctive settlements should be banned.

Proposition 4 A reverse antidumping settlement should be prohibited if the expected gain to consumers from entry exceeds the plaintiff's cost of litigation $\left((1-P) W>C_{p}\right)$.

The argument for this runs as follows. From (1), we know that the reverse settlement is welfare reducing if $(1-P) W+(1-P) L_{d}>C_{p}+C_{d}$. If

\footnotetext{
14 On collusion and injunctive settlements of antidumping disputes, see Prusa (1992).

15 Prusa (1992) provides empirical evidence that settled antidumping disputes are associated with reductions in trade that are at least as large as those resulting from adjudicated disputes.
} 
$(1-P) L_{d}>P D+C_{d}$, then a reverse settlement is feasible (see Part II), and it will be welfare reducing whenever $(1-P) W>C_{p}$. The final step of the argument is to show that a reverse settlement is unlikely to be observed when $(1-P) L_{d}<P D+C_{d}$ (i.e., defendant does not need to receive money to settle). This is implied by the Landes-Posner-Gould model and the fact that the plaintiff moves first by filing. Given that he moves first, the plaintiff will always make a positive demand that is within the settlement zone if $(1-P) L_{d}<P D+C_{d}$, and the parties will settle. Otherwise (i.e., reversing the inequality), the plaintiff will offer the smallest reverse payment necessary to settle.

The condition $(1-P) W>C_{p}$ is likely to hold because $C_{p}$ will be relatively small. The reason is that the plaintiff spends relatively little because a government agency prosecutes the complaint; the agency's costs are largely fixed and the burden of producing evidence is largely on the defendant/foreign entrant. It follows, then, that social welfare could be improved by banning the reverse injunctive settlement in the antidumping context.

Since antidumping injunctions lead to inefficient results, the suggestion that the reverse injunctive settlement be banned should not be seen as a surprise. Still, in the presence of substantial litigation costs, it is not clear that every reverse injunctive settlement will be socially undesirable. Proposition 2 shows that the case for banning reverse injunctive settlements remains strong in the antidumping context, even with substantial litigation costs taken into account.

There are other settings that share the general structure of the antidumping problem. A hush money settlement saves society litigation expenses, but may also impose welfare costs (Daughety and Reinganum 1999). Or consider the procurement setting, with two contractors. The incumbent contractor can seek to have the efficient entrant contractor deemed ineligible, a costly process like litigation (Marshall et al. 1994). The incumbent may prefer to pay off the efficient entrant, which is the same as a reverse settlement.

\subsection{Patent antitrust and more general applications}

Unlike antidumping prosecutions, patent infringement cases cannot be treated as consistent-belief disputes with a high probability of plaintiff victory. Many of the disputes involve low-probability claims on the part of the plaintiff patent holder and disparate beliefs as to the plaintiff's likelihood of success. On the other hand, in many of the patent infringement cases the plaintiff's gain from the injunction exceeds the defendant's loss. Given this, and the foregoing analysis, the reverse settlement should be taken as a sign of potentially harmful welfare consequences in the patent-antitrust context. ${ }^{16}$

However, the patent infringement setting is more complicated than the antidumping setting. The patent infringement cases involve dynamic innovation incentives and static demand-inducement incentives that are likely to be affected by the willingness of courts to grant competition-blocking injunctions.

\footnotetext{
16 There is a large literature identifying the potential welfare costs of reverse settlements in the patent context. See, e.g., Shapiro (2003), Hovenkamp et al. (2003), Cotter (2004).
} 


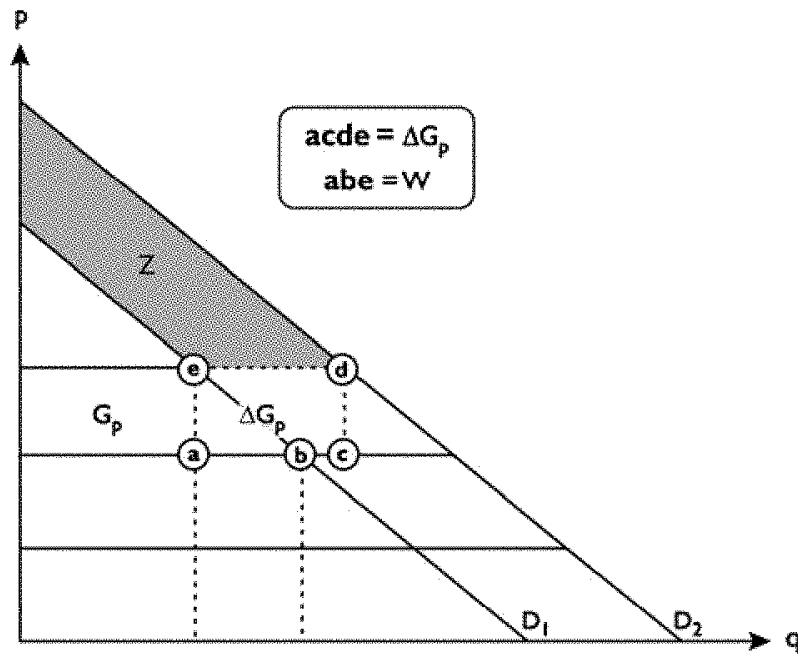

Fig. 2 Diagram of static efficiency gain due to demand inducement

Consider the static demand-inducement factor. Suppose the plaintiff firm-e.g., a drug company-invests in creating demand for its new product-a drug. If the injunction is awarded in its favor, it will have an incentive to continue to invest in promotion. Thus, unlike the antidumping scenario, excluding the low-cost rival causes supports product promotion, which causes the demand curve to shift outward, as in Fig. 2.

Because the injunction itself could be socially desirable, the injunctive settlement could be socially desirable. However, we do not know in advance whether a particular injunction is socially desirable-that is, we do not know in advance whether the dispute is best characterized by Fig. 1 or by Fig. 2 .

\subsubsection{Modifying the basic model}

The settlement model can be modified to take into account the special considerations in patent infringement litigation. The new features to take into account are the static and dynamic efficiency effects. As in Fig. 2, let $\Delta G_{p}$ represent the captured portion of the static efficiency gain.

The dynamic incentive is difficult to model from the ground up, but we will simplify matters by assuming that there is a potential dynamic incentive cost resulting from the rejection of the plaintiff's infringement claim. Let the social cost of the dynamic incentive effect be $\Psi$. The social cost is likely to be a function of the ex ante probability of infringement. ${ }^{17}$ For example, if the ex ante probability of infringement is close to zero because the patent is invalid, then the social cost of a rejection of the plaintiff's infringement claim is probably close to zero. As a general

17 The term ex ante probability of infringement was introduced in Crane (2002). Crane suggests that the social cost of rejecting an infringement claim is positively correlated with the ex ant probability of infringement (Crane 2002, at 780). 
rule, then, the social cost of the dynamic incentive effect is an increasing function of the ex ante probability of infringement. ${ }^{18}$ The portion of the social cost borne by the plaintiff will be represented by $\gamma \Psi$.

Using Proposition 1, any injunctive settlement will be a reverse payment settlement. The reverse payment (injunctive) settlement is desirable to the infringement plaintiff if

$$
S+G_{p}+\Delta G_{p}>P_{p}\left(G_{p}+\Delta G_{p}+D\right)-C_{p}-\left(1-P_{p}\right) \gamma \Psi
$$

where $S<0$, and the last term reflects the plaintiff's perception of the dynamic incentive cost of losing his patent monopoly. The condition determining whether the settlement is desirable to the defendant is the same as in the basic model examined in the part III.

An injunctive settlement will be desirable, as between the litigating firms, when

$$
\left(1-P_{d}\right) L_{d}-\left(1-P_{p}\right)\left(G_{p}+\Delta G_{p}\right)+\left(P_{p}-P_{d}\right) D-\left(1-P_{p}\right) \gamma \Psi<C_{p}+C_{d}
$$

To simplify, consider the consistent beliefs case, where the injunctive settlement condition becomes

$$
(1-P)\left(L_{d}-G_{p}-\Delta G_{p}-\gamma \Psi\right)<C_{p}+C_{d},
$$

or

$$
L_{d}<G_{p}+\Delta G_{p}+\left(C_{p}+C_{d}\right) /(1-P)+\gamma \Psi .
$$

Incorporating efficiencies does not greatly change the analysis from the basic model examined earlier in this paper. Note that if $G_{p}>L_{d}$ then a reverse settlement will occur in any setting in which entry is desirable to defendant and the plaintiff has an incentive to file an infringement action (Proposition 3). The scope for injunctive settlements expands because the gain to the plaintiff is now greater than in the previous analysis (because of the static efficiency effect), and because the cost of failing to settle is greater too (because of the dynamic efficiency effect).

$P$ represents the objective probability that the plaintiff will prevail, or the ex ante probability of infringement. We can also treat $P$ as an index of the patent's validity. ${ }^{19}$ Using Fig. 2, injunctive settlements should be banned if

$$
(1-P)\left[W+L_{d}-\left(\Delta G_{p}+Z\right)\right]>C_{p}+C_{d}+(1-P) \Psi
$$

The first two terms on the left hand side of (6) equal the expected welfare gain from competitive entry. The next two terms, $\left(\Delta G_{p}+Z\right)$, equal the static efficiency

\footnotetext{
18 More precisely, the social cost will be a function of the probability that the patent is valid and that it was infringed, and it should be an increasing function in both variables. However, the marginal contribution of each variable to the social cost will not be the same. The social cost is also a function of the wealth generated by the patent incentive. The wealth generated by a patent is the sum of the consumer surplus and monopoly profits generated by the patent. Specifically, the term $\gamma \Psi$ will be determined in part by the expected stream of patent profits forgone because of the discouragement effect. The remainder term $(1-\gamma) \Psi$ will be determined in part by the expected residual consumer welfare forgone because of the discouragement effect. These terms are capable of estimation.

${ }^{19} P$ is the product of the probability of validity and the probability of infringement (assuming the two are independent). Treating it as an index of patent validity is clearly imprecise because it implicitly assumes that the probability of infringement is one.
} 
gain from the injunction. The last term on the right hand side is the expected dynamic efficiency loss. It should be clear that $(1-P)\left[W+L_{d}-\left(\Delta G_{p}+Z\right)-\Psi\right]$ is the social return from litigation. ${ }^{20}$ The injunctive settlement should be banned if the social return from litigation exceeds the cost of litigation.

Thus, in patent infringement litigation, banning the injunctive settlement is socially desirable only if the expected welfare gain from competitive entry exceeds the static efficiency gains from the injunction, the cost of litigation, and the dynamic incentive cost.

As suggested in Shapiro (2003), the strength of the underlying patent infringement claim $P$ plays an important role in determining the social desirability of an injunctive settlement. However, the scope of the patent and the market, the size of the efficiency gain from entry, static and dynamic efficiency costs, ${ }^{21}$ and litigation costs also play a role. These factors suggest that a rule of reason analysis of competition blocking settlements in the patent setting could be quite complicated.

\subsubsection{Incentive alignment and optimal penalty}

Given the ambiguous welfare effects of the injunctive settlement in the patent context, one solution to the settlement problem is to alter the incentives of the plaintiff so that he seeks an injunctive settlement only under conditions in which it is socially desirable.

4.3.2.1 Incentive alignment under consistent beliefs Consider an example in which the parties have consistent beliefs. The private settlement condition (3) can be used with the social incentive condition (6) to determine a penalty (or subsidy) that would align the incentives of the individual firms with the social incentive on settlement. If the plaintiff is required to pay,

$$
G_{p}+W-Z-(1-\gamma) \Psi
$$

upon gaining his injunction, then the social incentive to settle will be the same as the private incentive to settle, ${ }^{22}$ which means that the parties will seek a settlement only

\footnotetext{
${ }^{20}$ If there is a strong correlation between $\Psi$ and $P$, the social return from litigation should be expressed as $(1-P)\left[W+L_{d}-\left(\Delta G_{p}+Z\right)-\Psi(P)\right]$, which reflects the assumption of Crane (2002). If $\Psi$ increases strongly in $P$, then the social return to litigation would not only approach zero as $P$ increases, but is also more likely to be negative for high $P$ values. Focusing on $P$ might serve as a short cut to trying to determining the social return from patent litigation. In general, the relationship between $\Psi$ and $P$ is an empirical question.

21 The dynamic incentive effect is emphasized in Langenfeld and Li (2004) and in Blair and Cotter (2002).

22 If the penalty is set equal to (7) the plaintiff's net reward will be $G_{p}-\left(G_{p}+W-Z-(1-\gamma) \Psi\right)=$ $-W+Z+(1-\gamma) \Psi$. This implies that the private settlement condition will be equivalent to the social settlement condition. Specifically, the private joint payoff from litigation is $(1-P)\left(L_{d}-G_{p}-\Delta G_{p}-\gamma \Psi\right)$. The social payoff from litigation is $(1-P)\left[W+L_{d}-\left(\Delta G_{p}+Z\right)-\Psi\right]$. When the penalty is set according to $(7)$, these payoffs are the same.
} 
when it is socially desirable. The optimal penalty requires the plaintiff to regurgitate the monopoly rent and to pay for the deadweight loss; however, it also subsidizes the plaintiff an amount equal to the "uncaptured" static and dynamic efficiency gains. The optimal penalty should be applied to the monopolist whether it gains its injunction through a court order or through settlement.

The optimal penalty in (7) is a generalized version of the monopolization penalty of Landes (1983). If the static and dynamic efficiency effects are zero, as in the antidumping scenario, the optimal penalty is equal to the monopoly transfer plus the deadweight loss $\left(G_{p}+W\right)$. Similarly, if the static efficiency gain is captured completely by the monopolist and the dynamic cost is borne in its entirety by the monopolist, the optimal penalty is again equal to the monopoly transfer plus the deadweight loss.

\subsubsection{Incentive alignment and inconsistent beliefs We have so far considered} incentive alignment in the case of consistent beliefs. The optimal penalty would require the monopolist to pay for the welfare transfer from consumers as well as the deadweight loss, and subsidize the monopolist to the extent of uncaptured static and dynamic efficiency gains. We explore in this section whether this approach remains valid in cases in which the litigants have inconsistent beliefs regarding the ex ante probability of infringement.

First, consider the setting in which litigating parties' beliefs are consistent with the Priest and Klein (1984) hypothesis. Trial-outcome predictions diverge but only because of random differences in beliefs. Under the Priest-Klein model, trialoutcome beliefs are generated according $P_{d}=P+\varepsilon_{d}, P_{p}=P+\varepsilon_{p}$, where $\varepsilon_{d}$ and $\varepsilon_{p}$ have mean zero, and where $P$ is the objective estimate of the likelihood of a verdict for the plaintiff (the probability of a finding of patent infringement) (Hylton 2006). If the optimal penalty is imposed on the patent holder then settlement will be acceptable to the parties when

$$
\begin{aligned}
& (1-P)\left(W-\left(\Delta G_{p}+Z\right)+L_{d}-\Psi\right)-\varepsilon_{p}\left(W-\left(\Delta G_{p}+Z\right)-\Psi\right)-\varepsilon_{d} L_{d} \\
& \quad+\left(\varepsilon_{p}-\varepsilon_{d}\right) D<C_{p}+C_{d}
\end{aligned}
$$

and since $\varepsilon_{p}$ and $\varepsilon_{d}$ have mean zero, the private and social incentives to settle will be the same in expectation. Thus, in the Priest-Klein scenario, the optimal incentive alignment penalty accomplishes its objective. ${ }^{23}$

Now consider the inconsistent beliefs scenario where $P_{d}=P, P_{p}=P+Q$, and $1-P>Q>0$. The defendant's prediction is equal to the objective probability of infringement, while the plaintiff overestimates the likelihood the patent will be upheld. The joint private return from litigation is equal in expectation to

$$
(1-P)\left(L_{d}-G_{p}-\Delta G_{p}-\gamma \Psi\right)+Q\left(G_{p}+\Delta G_{p}+\gamma \Psi\right)+Q D
$$

\footnotetext{
23 The Priest-Klein generates a plaintiff win rate prediction of $50 \%$. This is consistent with the evidence on patent litigation. Plaintiff win rates in patent infringement litigation are roughly $50 \%$, see Allison and Lemley (1998). Thus, the empirical evidence suggests that patent infringement trials can be described by the Priest-Klein model. However, this does not imply that half of patents are invalid. The evidence on win rates shows that only the most uncertain patents are litigated all the way to judgment, and that within the sample of litigated patents plaintiffs are no better than defendants at determining the validity of the patent.
} 
where the first term reflects the potential net gain if the injunction is overturned. The last two terms reflect the differences in the parties' expectations of the trial outcome. Recall that the social return from litigation is equal to $(1-P)$ $\left(W+L_{d}-\left(\Delta G_{p}+Z\right)-\Psi\right)$.

The optimal penalty equates the private and social returns from litigation. Unlike the Priest-Klein scenario, the optimal penalty is no longer the generalized monopolization penalty (Landes 1983) in (7). In this case, the optimal penalty is

$$
G_{p}+\delta(W-Z-(1-\gamma) \Psi)+(1-\delta)\left[Q\left(\Delta G_{p}+\gamma \Psi+D\right)\right]
$$

where $\delta=(1-P) /(1-P-Q)>1$. The intuitive explanation for (10) is easier seen under the assumption that there are no static or dynamic efficiency concerns, in which case the optimal penalty would be

$$
G_{p}+\delta W+(1-\delta) Q D .
$$

Since the litigation decision is influenced by the divergent trial-outcome expectations of the parties, the optimal penalty reduces the relative importance of this effect by increasing the weight on $W$. In addition, since divergent expectations already push the parties into litigation, there is a lesser need in this case to use a large penalty (because some monopolies will be overturned by the court). This is the reason for the last term in (11), which is negative.

The lesson suggested here is that when divergent beliefs (or asymmetric information) drive the parties into litigation (because plaintiffs believe that the likelihood of a finding of infringement is greater than defendants think it is), the optimal penalty is less than it would be under consistent beliefs (7) because the worst-case monopolization scenario will be overturned more often in the courts. Conversely, when divergent beliefs cause the parties to litigate less frequently than they would under consistent beliefs (because defendants believe the likelihood of a finding of infringement is less than plaintiffs think it is), the optimal penalty will be greater than it would be under consistent beliefs.

\subsubsection{Waivers}

A policy of banning reverse or injunctive settlements would lead parties to opt for pre-dispute settlements, or waivers. Since the private and social returns from litigation are not the same, predispute waivers will be exchanged under conditions in which they may not be socially desirable.

Some patents are infringed intentionally. In other cases, the rival firm infringes the patent because it has not taken care (e.g., engaged in a search of patent records) to avoid the infringement. It follows that the infringement problem can be treated like that of accidental injuries.

Suppose the rival firm has a choice of taking care (search) or not taking care (no search). Let $x$ be the cost of taking care to avoid infringement. Let $\lambda_{c}$ be the probability that infringement occurs when the rival firm has taken care, and let $\lambda_{n c}$ be the probability that infringement occurs when the rival firm has not taken care. 
We will make a few simplifying assumptions for the analysis of waiver agreements. First, we will assume consistent beliefs regarding the patent's validity $\left(P_{p}=P_{d}=P\right.$ ). Second, in the analysis below we will assume that the patent holder loses his monopoly only through some conduct by the rival that could form the basis of an infringement claim-even if it is not technically infringement. This rules out instances in which the rival firm takes some action that causes the incumbent to lose its monopoly, but the incumbent has no credible basis at all for an infringement claim. Third, we will simplify matters by assuming that the patent holder does not introduce any ex post static efficiencies (e.g., demand inducement). Fourth, we will assume that maintenance of the patent monopoly is socially desirable, which means that $\Psi-W-L_{d}>0$.

A patent holder could enter into a predispute waiver, in which the monopolist agrees not to sue the rival for infringement. First, let's consider a standard waiver. In a standard waiver, the potential plaintiff (patent holder) accepts a payment in exchange for an agreement not to sue the rival firm when it infringes the patent. The minimum price demanded by the patent holder for the waiver is

$$
\lambda_{n c}\left(G_{p}+\gamma \Psi\right)-\left[\lambda_{c}(1-P)\left(G_{p}+\gamma \Psi\right)+\lambda_{c} C_{p}\right] .
$$

This is the difference between the patent holder's expected loss in the absence of the right to sue for infringement and his expected loss given the right to sue for infringement. ${ }^{24}$ The maximum offer from the rival (or potential defendant) would be

$$
x+\lambda_{c} C_{d}+\lambda_{c} P L_{d},
$$

which reflects the expected costs of search, litigation, and infringement liability. ${ }^{25}$ It follows that a standard waiver will be exchanged when

$$
\left(\lambda_{n c}-\lambda_{c}(1-P)\right)\left(G_{p}+\gamma \Psi\right)-\lambda_{c} P L_{d}-x<\lambda_{c}\left(C_{p}+C_{d}\right) .
$$

In other words, when the joint benefits of deterrence, as between the two parties, are less than the total cost of litigation, a standard waiver will be exchanged.

Now let us consider an injunctive waiver. In the injunctive waiver, the potential plaintiff (patent holder) accepts (or gives) a payment in exchange for an agreement not to sue the rival and for the rival to forgo the infringing activity.

The injunctive waiver is acceptable to the potential plaintiff if

$$
S+\lambda_{n c}\left(G_{p}+\gamma \Psi\right)>\lambda_{n c}\left(G_{p}+\gamma \Psi\right)-\left[\left(\lambda_{c}(1-P)\left(G_{p}+\gamma \Psi\right)+\lambda_{c} C_{p}\right]\right.
$$

The second term on the left hand side reflects the assumption that the monopolist will lose nothing in the event that an infringing act takes place, because the waiving defendant will immediately forgo the infringing conduct. As a result, the injunctive waiver is far more valuable to the patent holder than is the standard waiver.

\footnotetext{
${ }^{24}$ For the formal analysis of waiver incentives in the context of ordinary litigation, see Hylton (2000).

25 To simplify we are ignoring the possible damage claim component, which would be purely speculative at the stage of a waiver negotiation. Moreover, under the Hatch-Waxman Act, pioneer drug developers can file infringement suits after being notified that a generic intends to enter the market (see, e.g., Blair and Cotter 2002, at 505-506). This model applies especially to litigation under the Hatch-Waxman provisions, which is the most common source of reverse patent settlements today.
} 
The injunctive waiver is acceptable to the potential defendant if

$$
S+\lambda_{n c} L_{d}<x+\lambda_{c} C_{d}+\lambda_{c} P L_{d} .
$$

An injunctive waiver will be mutually agreeable when:

$$
\left(\lambda_{n c}-\lambda_{c} P\right) L_{d}-\left[\lambda_{c}(1-P)\left(G_{p}+\gamma \Psi\right)\right]-x<\lambda_{c}\left(C_{p}+C_{d}\right)
$$

Finally, consider the social interest in waivers. In a setting in which no one litigates, so patents are infringed at will, the social cost would be

$$
\lambda_{n c}\left(\Psi-W-L_{d}\right)
$$

With infringement litigation available, the total social cost is

$$
x+\lambda_{c}(1-P)\left(\Psi-W-L_{d}\right)+\lambda_{c}\left(C_{p}+C_{d}\right)
$$

It follows that patent litigation is not socially desirable if

$$
\left[\lambda_{n c}-\lambda_{c}(1-P)\right]\left(\Psi-W-L_{d}\right)-x<\lambda_{c}\left(C_{p}+C_{d}\right),
$$

which means that the social benefit from deterring infringement less the cost of avoiding infringement is less than the patent litigation costs. Even if all patents are socially desirable, patent litigation may not be socially desirable.

More importantly, comparing the social waiver incentive condition (20) to the private waiver incentive conditions [(17) and (14)], it is clear that the private and social incentives for waiving infringement litigation are not the same. Because of the externalities present in the patent context, the private waiver incentive conditions diverge from the social waiver conditions. This is not true in the normal (e.g., tort) litigation context, where the private waiver condition and the social waiver condition are the same (Hylton 2000).

In the standard litigation context, predispute waivers provide a Coasean solution to the problem of inefficient litigation. ${ }^{26}$ In the patent infringement setting, private waiver agreements do not provide a solution to the problem of inefficient infringement litigation.

There is more to be said about the private and social incentive conditions for waivers. First, compare the standard private waiver condition (15) to the social waiver condition (20). They imply the following:

Proposition 5 If the probability of infringement is the same whether or not the rival takes care $\left(\lambda_{n c}=\lambda_{c}\right)$, then the optimal penalty $G_{p}+W-(1-\gamma) \Psi$ guarantees that standard waivers will be exchanged when and only when patent infringement litigation is socially undesirable.

To see this note that if $\lambda_{n c}=\lambda_{c}$, then (14), the condition for privately optimal waivers, becomes

$$
\lambda_{c} P\left(G_{p}+\gamma \Psi-L_{d}\right)-x<\lambda_{c}\left(C_{p}+C_{d}\right)
$$

and (20), the condition for socially optimal waivers, becomes

\footnotetext{
${ }_{26}$ On the inefficiency of litigation, see Shavell (1982b). On waivers as a Coasean solution, see Hylton (2000).
} 


$$
\lambda_{c} P\left(\Psi-W-L_{d}\right)-x<\lambda_{c}\left(C_{p}+C_{d}\right)
$$

Thus, if $\lambda_{n c}=\lambda_{c}$, and if the monopolist pays a penalty equal to $G_{p}+W-(1-\gamma) \Psi$, private waivers allowing infringement to occur will be exchanged when and only when patent litigation is socially undesirable. If the probability of infringement is not independent of the care taken by the rival, then the optimal penalty is more complicated. ${ }^{27}$

Now compare the injunctive waiver condition (17) to the social waiver condition (20). If $\lambda_{n c}=\lambda_{c}$, then (17) becomes

$$
\lambda_{c}(1-P)\left(L_{d}-G_{p}-\gamma \Psi\right)-x<\lambda_{c}\left(C_{p}+C_{d}\right)
$$

and it is socially desirable to enforce patents when

$$
\lambda_{c} P\left(\Psi-W-L_{d}\right)>x+\lambda_{c}\left(C_{p}+C_{d}\right)
$$

If the monopolist is required to pay the penalty $G_{p}+W-(1-\gamma) \Psi$, then the private incentive for the exchange of injunctive waivers (preventing infringement) becomes

$$
\lambda_{c}(1-P)\left(\Psi-W-L_{d}\right)>x+\lambda_{c}\left(C_{p}+C_{d}\right) .
$$

Proposition 6 If the probability of infringement is the same whether or not the rival takes care $\left(\lambda_{n c}=\lambda_{c}\right)$, and if the ex ante probability of infringement is greater than $50 \%(P \geq 1 / 2)$, then the optimal penalty $G_{p}+W-(1-\gamma) \Psi$ guarantees that injunctive waivers will be exchanged only when patent infringement litigation is socially undesirable. ${ }^{28}$

These results show that the internalization approach to the optimal penalty $(8)$ is a possible solution to the incentive alignment problem in the waiver setting, but only under special conditions. Specifically, the optimal penalty aligns private and social incentives to settle, and to waive, if the probability of infringement is the same whether or not the firm conducts a search.

Although the incentive alignment approach is possible in the waiver context, it requires much more information than in the settlement context. The informational requirements are so steep, in the waiver context, that the optimal penalty approach may not be a practical solution.

\subsubsection{Risk aversion, clouds over patents, and other costs}

There are other costs that could be incorporated into the model of this paper. Some commentators have noted that risk aversion is a factor that drives some patent holders to seek injunctive settlements. ${ }^{29}$ In any event, the cost of risk could be incorporated into this analysis as another cost that, like litigation costs, the parties can avoid by entering into a settlement.

\footnotetext{
${ }^{27}$ The optimal penalty in the general standard waiver case is $G_{p}+W-(1-\gamma) \Psi+\left[\left(\lambda_{n c}-\lambda_{c}\right) /\right.$ $\left.\left(\lambda_{n c}-\lambda_{c}(1-P)\right)\right] L_{d}$. The last term is an additional charge to the monopolist because his contract has increased the rate of infringement and at the same time denied society the gain from that increased rate of infringement.

${ }^{28}$ The optimal penalty in the general injunctive waiver case is $G_{p}+\prod W-\left(\prod-\gamma\right) \Psi-[(1-2 P) /$ $(1-P))] L_{d}$, where $\prod=\left(\left[\left(\lambda_{n c}-\lambda_{c}(1-P)\right] / \lambda_{c}(1-P)\right)\right.$.

${ }^{29}$ See Crane (2002).
} 
Some commentators have pointed to the uncertainty surrounding the patent as a motivating factor behind injunctive settlements. A patent, as commentators have noted, is not a right to exclude, but a right to try to exclude. It is a probabilistic property right. ${ }^{30}$ However, the holder of a patent clearly has an incentive to increase its value by reducing the likelihood that it will be found insufficient as a bar to some rival.

Transaction cost reduction provides another motivation to seek an injunctive settlement. Patents are traded. If the uncertainty concerning validity can be reduced, it will be easier to trade in patents. Uncertainty is a transaction cost that obstructs efficient trades in the market for patents.

\section{Practical implications}

As a preliminary matter, the reverse payment settlements that have become controversial in competition-blocking litigation, particularly in the patent antitrust and antidumping settings, reflect features that are observed generally in injunctive litigation. The parties in injunctive litigation have the option of choosing a standard settlement that preserves the status quo or an injunctive settlement that implements the terms sought by the plaintiff. Both types of settlement are potentially wealth enhancing to the litigating parties, and to society as well, because they avoid expenditures on litigation. Injunctive settlements are likely where the gain to the plaintiff from the injunction exceeds the loss to the defendant. Reverse payment settlements are likely to be observed whenever the stakes from the injunction are large relative to the damages and the costs of litigation.

These general observations may take on a special importance in the context of competition-blocking litigation. The gain to the plaintiff from the injunction, in the competition blocking context, will be correlated with the consumer welfare loss from blocking competition. Injunctive lawsuits will tend to be filed in areas where the potential consumer harm is greatest. Injunctive settlements will be among those lawsuits with the greatest potential harm to consumers, and (virtually) all of them will be reverse settlements (Proposition 1). For these reasons, the suspicions concerning reverse settlements in the competition-blocking context are warranted.

Those suspicions, however, have to be balanced against the social welfare gains that are generated by reverse payment (injunctive) settlements. They reduce litigation costs. Moreover, if the reason for blocking competition is to support dynamic (innovation) or static efficiency incentives (market development), then the settlements may improve welfare in some cases. The mere fact that a large reverse settlement payment has occurred is not a sufficient basis for inferring that the settlement reduces social welfare. ${ }^{31}$ These straightforward observations have been disregarded in some of the critical discussions of reverse settlements.

\footnotetext{
30 Shapiro (2003)

31 If the stakes are sufficiently large, reverse payments will occur even though the likelihood of a finding of infringement is high. Moreover, if the dynamic efficiency cost is substantial, the reverse settlement may enhance social welfare. These are basic implications of the model in Part IV of this paper. It is in contrast to one of the most widely-accepted views in the patent-antitrust literature that a large reverse payment should be taken as a clear sign that the patent is invalid, see, e.g., Hovenkamp (2004, at 28)
} 
The core source of controversy surrounding injunctive settlements is that the social incentive to settle differs from the private incentive. This is also a feature observed generally in litigation. In the general litigation context, commentators have noted that parties may settle when it would be better from society's perspective if they litigated in order to enhance the stock of legal capital (Fiss 1984; Hylton 2000). The mere existence of litigation costs does not imply a divergence between private and social settlement incentives. Litigation costs (in most models) are borne entirely by the parties. Given this, any settlement achieved to avoid litigation costs is also consistent with social welfare. But once we consider broader societal effects from litigation-such as effects on the stock of legal capital or the congestion of courts - then we must recognize that the private and social settlement incentives diverge.

The divergence between private and social incentives is especially noticeable in the competition-blocking scenario. The reason is that there is a third party, the consumer, who is directly affected by the parties' settlement agreement.

\subsection{Variations on settlement}

The model in this paper assumes that the settlement agreement follows a legitimate competition-blocking lawsuit-such as an antidumping prosecution or a patent infringement claim. However, this need not be the case, and this raises some important issues that are not directly addressed by this model. One can expand the model to take these additional issues into account.

There are several types of competition-blocking settlements, some of which seem to fall outside of the model examined here. One type is a competition-blocking settlement that is reached in connection with a lawsuit that has no connection to competition. For example, the plaintiff could sue the defendant for defamation, and condition settlement on the defendant's agreement to stay out of his market. Suppose, for example, that the lawsuit is nothing more than a ruse to allow the parties to enter into a competition-blocking agreement under the cloak of settlement. If the lawsuit itself is ginned up for the sole purpose of cloaking an anticompetitive agreement, then both the social welfare loss from prohibiting competitive entry $\left(W+L_{d}\right)$ and the litigation costs are elements of waste. Unless there is some efficiency that is generated by the settlement, it should be considered per se illegal.

A second variation based on the settlement just mentioned is one attached to a legitimate lawsuit. Suppose the plaintiff brings a legitimate defamation lawsuit against the defendant and conditions settlement on the defendant agreeing to stay out of his market. The settlement saves society the litigation costs in this case. Still, the lawsuit itself could not have led to the same result. If there is no efficiency generated by the settlement, its social desirability will be determined by a comparison of the welfare loss and the avoided litigation costs.

Footnote 31 continued

("a firm willing to pay roughly $\$ 75$ million per year to keep an alleged infringer out of the market when a successful preliminary injunction would have done the same thing for the cost of obtaining the injunction indicates that the prospects for a preliminary injunction were very poor."). 
A third variation involves a real competition-blocking lawsuit, such as antidumping or patent infringement, that generates a settlement, as in this model; but the settlement is more restrictive of competition than the lawsuit itself. For example, the settlement may require the defendant to stay out of several markets. This variation is in fundamental respects the same as the second variation. Assuming no efficiency gain generated by the settlement, its social desirability will be determined by a comparison of the total welfare loss (including the loss due to the additional restrictions) and the avoided litigation costs.

There is a strong case for treating the second and third variations as per se antitrust violations. The settlement could be efficient in both cases. But the anticompetitive potential is clearly greater than in the case examined in the model of this paper. And since the anticompetitive potential is virtually limitless in the second and third variations, a per se rule may be appropriate.

These variations suggest the need for legal doctrines that distinguish settlements in (a) legitimate competition blocking lawsuits that are (b) within the boundaries of the lawsuit's anticompetitive effect. Settlements that do not satisfy these two conditions raise serious suspicions under the antitrust laws.

\subsection{Proposals for regulating settlements}

There are several types of proposals that have been suggested for regulating reverse payment injunctive settlements. Perhaps the simplest is to declare all such settlements per se unlawful under the antitrust laws. Hovenkamp et al. (2003) proposed that reverse settlements that exceed the cost of litigation should be deemed per se illegal. The FTC, in the Schering-Plough litigation, ${ }^{32}$ adopted this position, though it was rejected by the appellate court.

The analysis in this paper provides little support for such a per se prohibition. First, the reverse settlement is a signal that the gain to the defendant from competitive entry (equivalently, the defendant's loss from the injunction) is large relative to the damages and costs of litigation. That is consistent with the claim that the settlement poses a risk to consumers. However, the reason the plaintiff is willing to pay for the reverse settlement is that the plaintiff's gain from the injunction is also large relative to the damages and litigation costs. The plaintiff's gain could be large because of the static (market development) or dynamic (innovation) gains from the injunction. The mere fact that a large reverse payment is observed does not imply that the settlement reduces either overall social welfare of consumer welfare.

Suppose the reverse settlement is less than the total cost of litigation, which would be permitted under the Hovenkamp et al. proposal. It should be clear that the plaintiff and defendant can alter the terms of settlement to bring about this result, whatever the social welfare effects of their settlement. For example, the parties could agree to share all or parts of their markets rather than let the settlement payment be the only variable term of the agreement.

\footnotetext{
32 In re Schering-Plough Corp., No. 9297, at 12 (F.T.C. Dec. 18, 2003), htp://www.ftc.gov/os/adjpro/ d9297/031218commissionopinion.pdf, vacated, 402 F3d 1056 (11th Cir. 2005).
} 
Another per se rule was proposed in Crane (2002), which is to prohibit, on a per se basis, reverse payment injunctive settlements when the ex ante likelihood of a finding of infringement $(P)$ is low and to adopt a per se legality rule when the likelihood of a finding of infringement is high. This would require a preliminary determination of the likelihood of patent infringement as part of the antitrust trial. ${ }^{33}$

This paper's model indicates that there are other factors in addition to the ex ante likelihood of a finding of infringement that should be part of the analysis. Certainly if the ex ante likelihood of a finding of infringement is close to one the settlement should be permitted. This rule would be advisable even when there were no possible efficiency bases for enjoining competitive entry. If the ex ante likelihood of a finding of infringement is almost one, prohibiting the injunctive settlement would be socially harmful because it would force wasteful litigation expenses.

However, even if the ex ante likelihood of plaintiff success in the infringement suit is not high, a reverse settlement may be defensible on welfare grounds. The reason is that in addition to the static welfare losses created by the settlement, a social planner would have to take into account the potential efficiency gains from the injunction. For example, suppose the likelihood of a finding of infringement is only $50 \%$. Suppose the static welfare loss (from monopoly pricing) is $\$ 100$, the gain from competitive entry is $\$ 100$, and the total cost of litigation is only $\$ 20$. If there are no potential efficiency gains, the social gain from continued litigation would be $\$ 100$, and the cost of that litigation would be only $\$ 20$. It would make sense, then, to ban the reverse injunctive settlement. However, suppose the efficiency gain from market development is $\$ 180$. In that case, the expected social gain from continued litigation would be $\$ 10$, which is less than the total cost of litigation. Even if the ex ante likelihood of an infringement finding were only $40 \%$, it would still be desirable to permit the reverse injunctive settlement. This example shows that the potential efficiency gains do not have to overwhelm the potential static welfare losses for the reverse injunctive settlement to be socially desirable-and that is because of the existence of litigation costs. The greater the litigation costs, the less demanding society should be on the size of the potential efficiency gains and the ex ante likelihood of success in an infringement action. ${ }^{34}$

Shapiro (2003) proposes a standard that would require settlements to give consumers the same level of welfare in expectation that they would receive had litigation occurred. Although it is not clear how such a standard would be implemented, it probably would require a comparison of the expected static welfare losses with expected efficiency gains. Presumably the settlement would be permitted under this standard only when expected efficiency gains exceeded expected welfare losses. This approach ignores the risk of judicial error and litigation costs as factors

\footnotetext{
33 For arguments against such an approach, see Brodley and O'Rourke (2002). One obvious problem with Crane's proposal is that a "preliminary determination" of the patent infringement question could be such a costly and time consuming proceeding that it fails every test of its efficiency.

34 One factor that weighs in favor of Crane's approach is the fact that the social cost of rejecting an infringement claim is likely to be positive correlated with the ex ante probability of infringement. In light of this Crane's approach may be preferable because it comes close to the right answer in most cases without requiring an enormously difficult rule-of-reason analysis.
} 
that might justify a settlement on social welfare grounds. The basis for ignoring these factors is unclear. The risk of error and litigation expenses are real costs.

A rule-of-reason approach ${ }^{35}$ to the review of a reverse settlement should take into account the ex ante likelihood of a finding of infringement, the likely welfare losses (a function of the scope of the patent), efficiency costs, and litigation costs. Such a standard would be difficult to implement, and might lead to a recommendation to forbear from prohibiting reverse patent settlements unless there is clear evidence that market development and innovation incentives are not implicated by the dispute, which is likely to be rare. Judge Posner, in Asahi Glass v. Pentech Pharmaceuticals, ${ }^{36}$ suggests that injunctive settlements should be upheld unless there are "suspicious circumstances" indicating anticompetitive effect. ${ }^{37}$ Suspicious circumstances might indicate that the patent settlement agreement is merely a device to facilitate collusion. ${ }^{38}$ This approach could provide the basis for a rule of reason test of settlements. It would stay the hands of courts in cases where suspicious factors were not present. The danger is that courts may expand the set of suspicious circumstances to include factors that are not reliable signals of anticompetitive effect.

The strongest case for a per se prohibition of reverse settlements is offered by the antidumping setting. In the antidumping setting we observe a domestic cartel seeking to exclude a low-price foreign rival. The end result of a successful prosecution will be a reduction in consumer welfare. The plaintiff cartel is not involved in innovation or the creation of static efficiencies that might justify a protected market. In this scenario there is a strong case for prohibiting reverse settlements, or treating them as per se antitrust violations. Under the conditions in which a reverse settlement is attractive, the settlement will very likely reduce social welfare, because the litigation costs avoided will be much smaller than the expected welfare losses. However, even this "strongest case" does not extend to all injunctive settlements in the antidumping context. There may be cases in which the litigation costs are large relative to the expected welfare losses, and as a result the injunctive settlement could be socially beneficial.

Outside of the antidumping setting, the case for a per se prohibition of reverse settlements-even a conditional one based on the merits of the infringement claim or the size of litigation costs-becomes considerably weaker. In the patent antitrust setting, the per se approach requires society to forgo static and dynamic efficiencies that might be supported by the injunction.

Another approach to regulating settlements would remove antitrust immunity under the Noerr-Pennington doctrine for settlement agreements that are clearly anticompetitive (Cho 2009). The traditional argument against applying antitrust law

\footnotetext{
35 See Blair and Cotter (2002), suggesting a rule of reason approach to reverse patent settlements; see also Schildkraut (2004).

36289 F.Supp. 986 (N.D. Ill 2003).

37 Id. at 992 . Posner's opinion indicate that courts also try to distinguish legitimate from illegitimate settlements, as suggested in the discussion in part III.A of this paper.

38 Id.; see also Priest (1977). Brodley and O'Rourke (2002) prefer to use suspicious circumstances in a per se framework that would enable courts to infer anticompetitive intent.
} 
to prohibit anticompetitive settlement agreements is that they are merely the byproduct of litigation, and legitimate (not objectively baseless) litigation is immune from antitrust prosecution. ${ }^{39}$ An alternative approach for regulating settlements would involve the courts either narrowing the antitrust immunity granted to litigation, or treating anticompetitive settlements under a different set of rules. Although the proper way to distinguish undesirable settlements from the rest would be to weigh all of the factors mentioned earlier (ex ante likelihood of a finding of infringement, potential static welfare losses, potential efficiency gains, and litigation costs), an approximately correct result might be reached through an intent test based on objective evidence. Under such a test, if the plaintiff pressured the defendant to reach a settlement under conditions in which he knew or had reason to know that the likelihood of infringement $(P)$ is extremely low, the court would consider the settlement a sham.

One difficulty with all of the new proposals for using antitrust law to regulate settlements is that the regulatory effect can be evaded if the potential litigants enter into waiver agreements. Indeed, a per se ban on reverse payment settlements would simply cause firms to rush into waiver agreements.

This paper proposes a third approach to regulating injunctive settlements. That is to impose an optimal penalty (or subsidy) on to the plaintiff seeking to block competition. If the optimal penalty were imposed in the antidumping context, no firms would seek to block competition. In the patent context, an optimal penalty could be negative (i.e., a subsidy) so that firms may still attempt to block competition even when paying the penalty. The penalty, which generalizes the approach suggested in Landes (1983), would internalize the welfare losses (transfer plus deadweight loss) as well as the uncaptured efficiency gains.

The optimal penalty approach would be administratively difficult, but perhaps no more so than a rule of reason standard applied with accuracy. Indeed it might reduce administrative costs by switching the penalty assessment to some administrative process rather than using the courts to generate complicated legal doctrines to assess the legality of injunctive settlements.

The optimal penalty approach has the additional feature that it will not necessarily lose its regulatory impact if firms opt for waiver agreements. If the likelihood that infringement takes place is not greatly dependent on the patent search efforts of rival firms, the optimal penalty approach need not be changed in order to correct incentives even in the predispute waiver setting. On the other hand, if the likelihood of infringement does depend on the patent search efforts of rivals, then agencies could apply a different set of penalties to predispute injunctive waiver agreements.

\section{Conclusion}

This paper presents an economic analysis of injunctive and reverse settlements, and applies it to competition-blocking litigation in the patent-antitrust and antidumping

\footnotetext{
39 Professional Real Estate Investors, Inc. v. Columbia Pictures Industries, Inc., 508 U.S. 49, 60-61 (1993).
} 
settings. Because of the consumer welfare implications of settlements, some commentators have suggested competition-blocking settlements should be banned. The general issue is the divergence between private and social incentives to settle. This paper identifies the factors that account for that divergence and offers a framework for evaluating the welfare implications of competition-blocking settlements.

Acknowledgments For helpful comments the authors thank Scott Baker, Daniel Crane, Ben Depoorter, Michael Meurer, and Steve Shavell.

\section{References}

Allison, J. R., \& Lemley, M. A. (1998). Empirical evidence on the validity of litigated patents. AIPLA Quarterly Journal, 26, 185

Blair, R. D., \& Cotter, T. F. (2002). Are settlements of patent disputes illegal per se? Antitrust Bulletin, 47,491 .

Brodley, J. F., \& O'Rourke, M. (2002). Preliminary views: Patent settlement agreements. Antitrust, 16, 53.

Calvani, T., \& Tritell, R. W. (1986). Invocation of United States import relief laws as an antitrust violation. Antitrust Bulletin, 31, 527.

Cho, S. (2009). Anticompetitive trade remedies. North Carolina Law Review, 87, 357.

Cotter, T. F. (2004). Antitrust implications of patent settlements involving reverse payments: Defending a rebuttable presumption of illegality in light of some recent scholarship. Antitrust $L J, 71,1069$.

Crane, D. A. (2002). Exit payments in settlement of patent infringement lawsuits: Antitrust rules and economic applications. Florida Law Review, 54, 747.

Daughety, A. F., \& Reinganum, J. (1999). Hush money. RAND Journal of Economic, 30, 661.

Fiss, O. M. (1984). Against settlement. The Yale Law Journal, 93, 1073-1090.

Hemphill, C. S. (2006). Paying for delay: Pharmaceutical patent settlement as a regulatory design problem. New York University Law Review, 81, 1553.

Higgins, R. S. (2002). A short-run welfare analysis of FTC antitrust oversight of patent litigation settlements under the Hatch-Waxman Act. Antitrust Bulletin, 47, 661-677 (Winter).

Hovenkamp, H. (2004). Sensible antitrust rules for pharmaceutical competition. University of San Francisco Law Review, 39, 11.

Hovenkamp, H., Janis, M., \& Lemley, M. A. (2003). Anticompetitive settlement of intellectual property disputes. Minnesota Law Review, 87, 1719.

Hylton, K. N. (2000). Agreements to waive or to arbitrate legal claims: An economic analysis. Supreme Court Economic Review, 8, 209-263.

Hylton, K. N. (2006). Information, litigation, and common law evolution. American Law and Economics Review, 8, 33-61.

Hylton, K. N., \& Cho, S. (2010). The economics of injunctive and reverse settlements. American Law and Economics Review, 12, 181-203.

Landes, W. M. (1983). Optimal sanctions for antitrust violations. University of Chicago Law Review, 50, 652.

Langenfeld, J., \& Li, W. (2004). Economic analysis of patent settlement agreements: The implementation of specific economic tests, the evaluation of dynamic efficiency, and the scope of patent rights. University of San Francisco Law Review, 39, 57-80.

Marshall, R. C., Meurer, M. J., \& Richard, J.-F. (1994). Curbing agency problems in the procurement process by protest oversight. RAND Journal of Economic, 25, 297.

Priest, G. (1977). Cartels and patent licenses. Journal of Law \& Economic, 20, 309.

Priest, G. L., \& Klein, B. (1984). The selection of disputes for litigation. The Journal of Legal Studies, 13, 1.

Prusa, T. J. (1992). Why are so many antidumping petitions withdrawn? Journal of International Economics, 33, 1.

Schildkraut, M. G. (2004). Patent-splitting settlements and the reverse payment fallacy. Antitrust Law Journal, 71, 1033. 
Shapiro, C. (2003). Antitrust limits to patent settlements. RAND Journal of Economics, 34, 391.

Shavell, S. (1982a). Suit, settlement, and trial: A theoretical analysis under alternative methods for the allocation of legal costs. Journal of Legal Studies, 11, 55-81.

Shavell, S. (1982b). The social versus the private incentive to bring suit in a costly legal system. Journal of Legal Studies, 11, 333.

Taylor, C. T. (2001). The economic effects of withdrawn antidumping investigations: Is there evidence of collusive settlements. The Federal Trade Commission Working Papers No. 240. 
